\title{
Impact of Regional Trade Agreements on India's Agricultural Exports
}

\author{
Niti Bhasin* and Rinku Manocha**
}

\begin{abstract}
The rapid increase in the bilateral and regional trade agreements (RTAs) depicts a worldwide urge to liberalise and attain a more competitive platform for trade. Moreover, RTAs being negotiated are increasing the spectrum of product and service coverage. Elaborate RTAs include provisions relating to, inter alia, investment, labour, agriculture, and environment. This paper empirically examines the impact of two RTAs (SAFTA and APTA) on India's agricultural exports. The study uses panel data for the period 2001 to 2013 and gravity framework to capture India's agricultural exports with 16 Asian economies. Along with the traditional variables of gravity (economic size and distance), we also include exporter-importer labour participation ratio, taste differential, and trade openness of importing countries in our model specification. The impact of RTAs is captured with two dummy variables, one for SAFTA membership and the other for APTA membership. Our results indicate that India's agricultural exports are positively affected by export-importer labour participation ratio, economic size, trade openness (of importer economy) and presence of RTAs. Though the impact of both SAFTA and APTA membership are found to be positive, the results for APTA are found to be significant for Indian agricultural exports.
\end{abstract}

Keywords: Regional Trade Agreements, Agricultural exports, APTA, SAFTA, Fixed effects model, Hausman Taylor estimation.

\subsection{Introduction}

Regional Trade Agreements (RTAs) are the foundation of the multilateral trading mechanism and acting as engines to boost trade, enhance market access and strengthen relations with economies across the globe. A rapid increase in the bilateral and regional trade agreements depicts a worldwide urge to liberalise and attain a more competitive platform for trade. Moreover, regional trade agreements negotiated are increasing the spectrum of product and service coverage.

*Associate Professor, Department of Commerce, Delhi School of Economics, University of Delhi.

**Assistant Professor, Hindu College, University of Delhi. 
Currently, 612 RTAs are notified under WTO of which 406 are in force (www.wto.org). Regional trade agreements are managing and regulating a major proportion of the world trade. The major emphasis of RTAs is to facilitate the economies to reduce and even remove tariff (and non-tariff) barriers for free flow of goods, services and factors of production. The provisions under customary RTAs were broadly covering only trade and tariff structure. However, current RTAs are more diversified (and elabourated) and cover provisions relating to, inter alia, investment, trade in services, labour, agriculture, environment, and health.

The scope and domain of negotiating RTAs covering agricultural provisions are highly sensitive both for developing as well as developed economies. WTO provides rules and provisions regarding liberalisation of agricultural products. The objective is to bring reforms in agriculture sector by streamlining the existing global agricultural trading sector and to make it more market-oriented for member nations. Agricultural sector had extensive domestic support in terms of subsidies and import barriers. This led to over production and subsequently, dumping in the international market. Moreover, import barriers over-protected the domestic agriculture and led to undue restrictions on foreign products. This has resulted in a deformed international agricultural trading. In response to this, WTO came up with measures like reduction in domestic subsidies, reduction in the volume of subsidised exports and increasing the market access opportunities for agricultural products to promote fair and freer agricultural trade among member nations.

\subsection{Impact of RTAs on trade}

Economies participating in a trade bloc bring up policies and norms to ease and regulate trade among member nations. Reduction in tariff (and non-tariff) barriers stimulates the follow of goods and services among member nations. Trading blocs act as a domain for the participating members where they enjoy larger market size, cheaper goods, cost effective factors of production and curtailment in trading costs. Such an environment boosts trade among member nations and hence leads to trade creation. The prime objective of RTAs is to create trade among member nations. Therefore, success of any integration can be measured by the quantum of trade facilitated by the formation of a bloc. However, trade diversion may also take place as a result of RTAs when trade gets shifted from non-members to member nations. On account of favourable tariff available to member nations, RTA non-member may lose the market even though he may be more efficient, thereby causing trade diversion. 


\subsection{Trends of RTAs in India}

India's participation in regional and bilateral integration has been enlarging since 1990 (Figure 1). Till date, India has negotiated 20 RTAs of which 18 were entered into only after 1990. As of $31^{\text {st }}$ January, 2014, 8 free trade agreements, 4 economic integration agreements and 8 partial scope agreements have been negotiated and are in force. Currently, India is member of significant RTAs in Asian region such as ASEANIndia, APTA, SAPTA and other bilateral integration.

Figure 1: India's cumulative RTAs since 1988

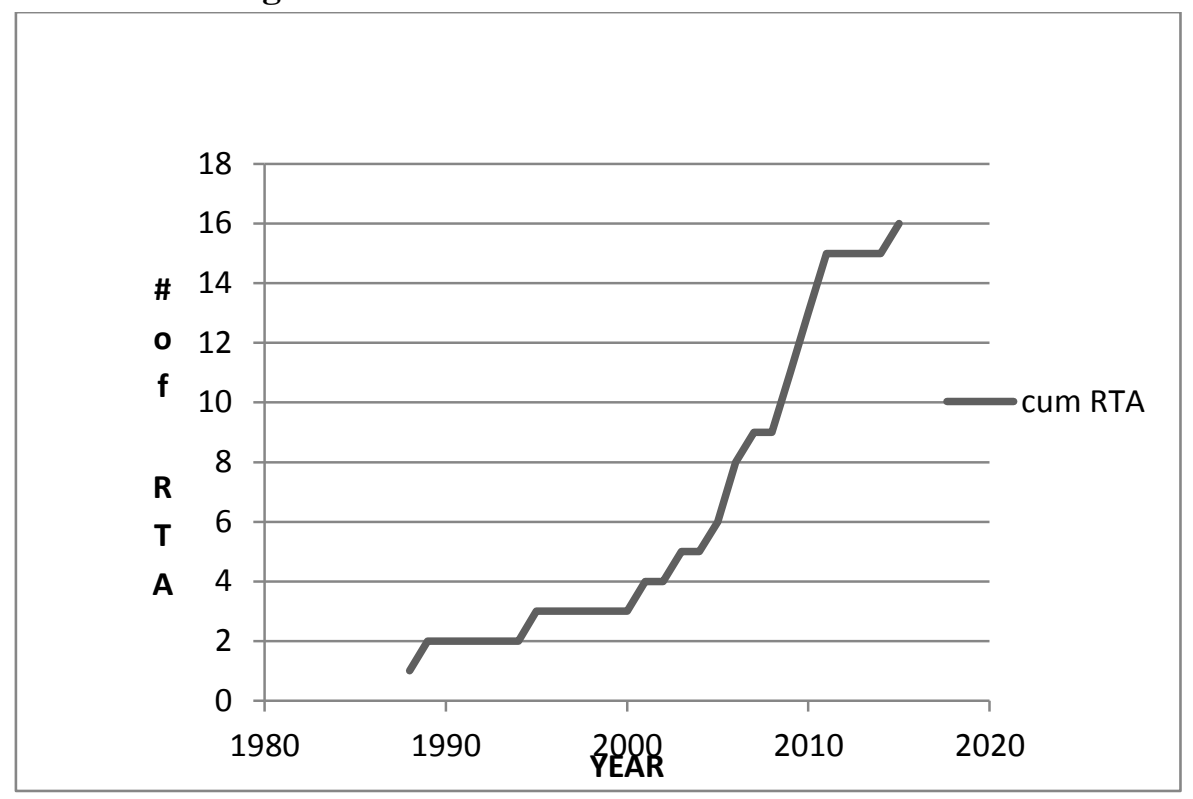

Source: Data collected from WTO database

The focus of our study is two significant regional trade agreements i.e. APTA (Asian Pacific Preferential Trade Agreement) and SAFTA (South Asian Free Trade Area) of which India has been an active member for more than a decade. These two preferential trade agreements were negotiated before 1999 and good coverage of these agreements include agricultural products. Therefore, we can easily examine the impact of these two major RTAs on India's agricultural exports over a period of time. APTA (Asian Pacific Preferential Trade Agreement) formerly known as Bangkok agreement was negotiated in 1976. Currently, China, Bangladesh, India, Republic of Korea, Lao People's Democratic Republic, and Sri Lanka are the member nations of APTA. In 2001, 
the total intra-APTA exports accounted for around 39 million (in thousand) US\$ and by the end of 2013, it had jumped to 348 million (in thousand) US\$ which shows a tremendous rise in the trade among the member nations. India has been an active member of APTA and Indian exports to APTA in 2013 was estimated around 32 million (in thousand) US\$ which is around $10 \%$ of total intra-APTA exports (www.trademap.com).

The second important RTA covered under the study is SAFTA, a regional trade negotiated among the SAARC nation to liberalise trade and strengthen economic relations. The agreement came into force in December, 1995 with seven member nations, Bangladesh, Bhutan, India, Maldives, Nepal, Pakistan and Sri Lanka. Indian intraSAPTA exports account for 16 million (in thousand) US\$ out of the total intra-SAPTA exports of 19 million (in thousand) US\$. India shares (around 85\%) the largest intraSAPTA export among all member nations. SAPTA came into force in 1995 to promote trade and economic cooperation in the region. However, SAFTA was a step ahead wherein all the seven members of SAPTA agreed to systematically phase out trade duties. SAFTA came into force in 2006. Intra-SAARC export value has increased around 8 times in the last decade but the intra-SAARC export value to the total world export for the region is only $4 \%$. Currently, there are eight members in the bloc, with the inclusion of Afghanistan.

\subsection{India's agricultural exports}

Along with a surge in the number of RTAs negotiated by India, there has also been a corresponding rise in Indian agricultural exports (Figure 2). India's agricultural exports mainly cover floriculture, fruits and vegetables, processed and semiprocessed fruits and vegetables, cereals and animal products. As per international agricultural trade report 2014, India's agricultural exports have climbed to $\$ 39$ billion in 2013 as compared to $\$ 5$ billion in 2003. India's net exports are almost double than EU28 and India ranks as sixth-largest net exporter in the world (International Agricultural Report, 2014).

\subsection{Rationale and Objectives of the Study}

Since the last two decades, the Indian economy has undergone a large number of structural and economic changes. However, agriculture still constitutes the major source of employment in India and India is one of the largest exporters of agricultural products in the world. Simultaneously, there have been efforts on the global front to liberalise and 
strengthen cross trade through regional economic integrations among nations. Therefore, it is imperative to look at the impact of existing RTAs on India's agricultural exports.

With this objective in mind, we examine the impact of two major RTAs (SAARC trading bloc and APTA) on India's agricultural exports. Our study is an effort to understand the determinants of India's agricultural exports with major emphasis on the behaviour of two significant RTAs of India and exporter-importer labour participation ratio.

Figure 2: India's agricultural exports since 1988

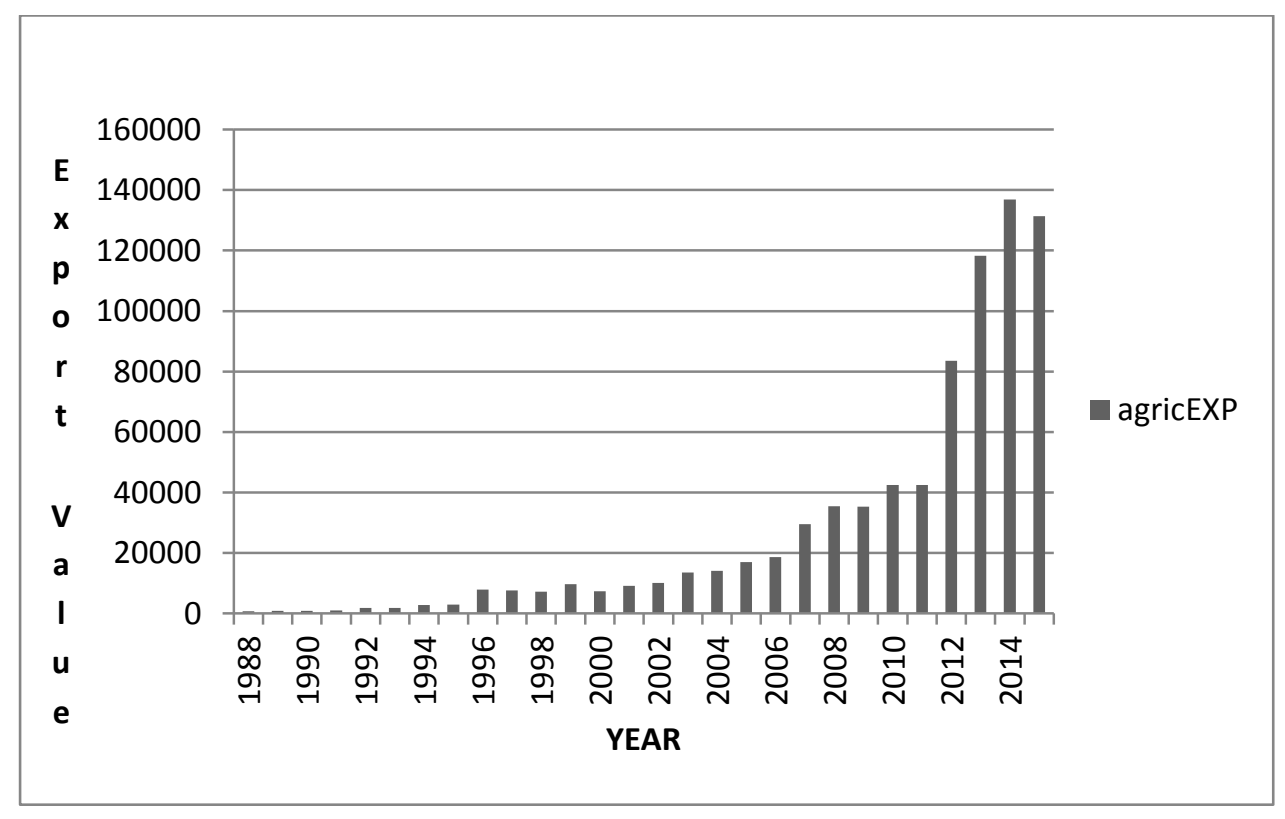

Source: Based on data collected from http://agriexchange.apeda.gov.in

\subsection{Literature Review}

A large numbers of studies have examined the impact of RTAs on bilateral trade/exports. Rahman, Shadat and Narayan(2006) focus on trade creation and trade diversion effects for few RTAs with major concern for SAFTA, using augmented gravity model with country-pair specific as well as year specific fixed effects. The study incorporates traditional gravity variables such as GDP, population, distance, common border, common language with bilateral exports flow as dependent variable. The study found that all member nations of SAPTA don't have equal results for trade creation and trade diversion. Bangladesh, Pakistan and India show positive signs for trade creation but other member nations of SAPTA show a negative export 
performance mainly due to structural limitation. Guilhot (2010) uses a panel data gravity model to assess the impact of three main East Asian Trade agreements (ASEAN, ASEAN-China, ASEAN-South Korea) over the period 1985-2007 to estimate the impact of intra-regional and extra-regional trade. The study incorporates 12 economies (10 ASEAN, South Korea and China) along with 22 main trading partners to determine the bilateral export flow. The study estimated positive and significant coefficient both for extra-bloc as well as intra-bloc trade.

Naseem and Ghani (2010) used gravity model based on cross-sectional and pooled data to measure the bilateral trade flows and trade effects for member and nonmember countries for a period of 2003 to 2008 years. The study covers the benefits of free trade agreements for SAARC countries and employs the gravity model of trade equation with bilateral trade flow as dependent variable. The study found trade diversion both for members as well as non-member SAARC nations. Lee and Shin (2005) cover 17 RTAs across the globe, using standard gravity variables along with some additional variables. The average value of real bilateral trade has been taken as dependent variable. Thy find that countries with cultural proximity and locational nearer along with RTA membership facilitate trade. Peter et al (2011) estimate the impact of RTAs in Africa, using gravity model for 35 countries for the years 1995-2006. Two major RTAs in Africa, ECOWAS and SADC are the focus of the study and are compared with the benchmark of integration, EU. The dependent variable is the total bilateral trade and export has been taken as the measure of total bilateral trade. The ECOWAS dummy variable is positive and highly significant but the results of SADC are found to be better than ECOWAS for intra-regional trade. The impact of overlapping membership has a positive coefficient. But the impact of overlapping membership for ECOWAS has been more significant and completely insignificant for SADC.

Muhammad and Yucer (2010) find whether RTAs have trade creation or trade diversion impact. The study uses gravity model with 38 countries covering six RTAs (ANDEAN, CARICOM, CACM, LAIA, MERCOSUR, and NAFTA) in the Western hemisphere for the year 1986-2006. Export from home to host country has been taken as dependent variable. All coefficients on trade creation variables are found significant except for NAFTA and LAIA. The trade diversion coefficient of NAFTA is significant and negative. MERCOSUR is also trade diverting. But ANDEAN and CACM are not trade diversion and they are creating trade both with members and non-members. LAIA, however has negative impact on trade 
both between members and non-members. Acharya (2012) aims to identify the trade(export, import and trade balance) determinants of Nepal using extended gravity model based on panel data for 21 major trade partners of Nepal. The study used both fixed and random effect model specification to examine the trade determinants. The study also found that Nepal exports more to SAPTA countries that non-SAFTA and imports less from OECD countries than non-OECD country. Study shows that the country specific fixed effects which are time-invariant factors also significant determinant of trade balance of Nepal.

The literature covering the impact of RTAs on agricultural trade/exports is very scarce. Vollrath and Hallahan (2009) conduct a study using panel data from 1975-2005 and gravity framework. The results provide strong empirical evidence that RTAs create trade in agricultural countries belonging to a common reciprocal agreement without diverting trade from non-member countries. Makochekanwa (2012) studies the impact of regional trade agreements on intra-trade for three selected agrifood products, maize, rice and wheat covering three regional agreements, the Common Market for Eastern and Southern Africa (COMESA), the East African Community (EAC) and the Southern Africa Development Community (SADC) for the period 2005 to 2010. The coefficients on all RTA variables, that is COMESA, EAC and SADC regional dummies, shows that, the overall estimated coefficients for these regional dummies in all commodities is positive and statistically significant. Jayasinghe and Sarker (2004) capture the trade creation and diversion effects of the North American Free Trade Agreement (NAFTA) on trade of six selected agrifood products from 1985 to 2000. The investigation estimates an extended gravity model using pooled cross-sectional time-series regression and generalized least squares methods. The result shows that the share of intraregional trade is growing within NAFTA and that NAFTA has displaced trade with the rest of the world. Korinek and Melatos (2009) examine the impact of three regional trade agreements (RTAs) - the ASEAN Free Trade Agreement (AFTA), the Common Market for Eastern and Southern Africa (COMESA) and the Southern Cone Common Market (MERCOSUR) on agricultural trade. Their results suggest that the creation of AFTA, COMESA and MERCOSUR have increased trade in agricultural products between their member countries.

\subsection{Data and Research Methodology}

We employ panel data regression on an extended gravity model. Conventionally, literature examining international trade has relied on the gravity framework suggested by 
Tinbergen (1962). The gravity framework captures the attraction of trade towards the economic size examined largely by GDP of both the trading partners and distance between the nations as a measure of trade cost. We employ an augmented gravity model to account for areas such as common border, commonality of language, and dummies to show membership of an RTA.

\subsection{Sample}

The study is conducted for a period of 13 years starting from 2001 onwards till 2013 to examine the impact of two RTAs (SAPTA and APTA) on India's agricultural exports (AgroExp). The Asian economies covered under the study are China, Vietnam, UAE, Bangladesh, Saudi Arabia, Malaysia, Indonesia, Thailand, Pakistan, Japan, Republic of Korea, Sri Lanka, Jordon, Philippines, Singapore and Nepal. These countries are the major importers of Indian agricultural products from India.

\subsection{Data sources}

Data for bilateral agricultural exports between India and its major Asian partner was collected from TradeMap via aggregating the HS code 2digits, 4 digits or 6 digits product which are covered as agricultural products under WTO (the list of the agricultural products and their respective harmonized code is given in Annexure 1). The data for bilateral agricultural exports is an aggregation of products covered under 'Agriculture' for each trading partner of India's export. The WTO definition of agriculture is used to quantify the agricultural exports. Data for GDP, GDP per capita and labour participation of both the trading partners was collected from World Bank database. The data for trade openness of the importer country (trade as a \% of GDP) was collected from UNCTAD. We gathered the data for regional integration from WTO RTA database. The details for bilateral distance, common language and common border were collected from CEPII (French research center for international economics).

\subsection{Model Specification}

The functional form for our gravity model capturing the determinants of India's agricultural exports is as follows:

$\log$ AgroEXijt $=(\log$ GDPit, $\log$ GDPjt, DIFFijt, LogLabRatioijt, LogTOPNjt, LogDISijt, Com_borijt, Ling_proijt, SAARCcijt, APTAcijt)

where $\log$ AgroEXijt is the bilateral agricultural export as the dependent variable.

$\log$ AgroEXijt, represents log of agricultural exports flows from India i to partner country $\mathrm{j}$ for the given year $\mathrm{t}$, $\log \mathrm{GDP}_{\mathrm{it}}$, the $\log$ of GDP of country $\mathrm{i}$ for given year $\mathrm{t}$, 
$\log \mathrm{GDP}_{\mathrm{jt}}$, the $\log$ of GDP of country $\mathrm{j}$ for given year $\mathrm{t}$,

DIFFijt $t_{i}$, absolute difference between the log of GDP per capita of country $i$ and $\log$ of GDP per capita of country $j$ for given year $t$,

$\operatorname{logDIST} \mathrm{ijt}_{\mathrm{ij}}$, the $\log$ of distance between the two countries $\mathrm{i}$ and $\mathrm{j}$ for given year $\mathrm{t}$,

$\log$ TOPENjt, the log of trade openness of host country $\mathrm{j}$ for given year $\mathrm{t}$.

$\operatorname{logLabratioijt,~the~log~of~exporter-importer~labour~participation~ratio~for~the~given~year~} \mathrm{t}$,

Com_borijt, dummy variable with value 1 if both the countries $i$ and $j$ are sharing common border otherwise 0 ,

Ling_proxijt, dummy variable with value 1 if both the countries $i$ and $j$ are sharing common official or ethnic language otherwise 0 ,

SAARC $_{i j}$, dummy variable with value 1 if both the countries $i$ and $j$ are part of SAPTA for a given year $t$ otherwise 0 ,

APTAcij, dummy variable with value 1 if both the countries $i$ and $j$ are part of APTA for a given year $t$ otherwise 0 ,

\subsection{Independent variables}

GDP of India (GDPit) captures the economic expanse (or size) of the exporting country. The variable has been incorporated to quantify the serving strength of India. The variable also outlines the agricultural produce the economy is willing to offer. Larger economic size is expected have a positive impact on agricultural exports.

$\mathrm{H}_{1 \mathrm{o}}$ : GDP of India does not affect India's agricultural export.

$\mathrm{H}_{1 \mathrm{a}}$ : GDP of India positively affects India's agricultural export.

GDP of the importing country (GDPjt) measures the extent of soaking capacity of the partner economy. Larger is the economic size of the trading partner, more is the need for necessary goods and hence more demand for primary products like agriculture produce. Therefore, the variable is expected to have a positive impact on the agricultural exports of India.

$\mathrm{H}_{2 \mathrm{o}}$ : GDP of trading countries do not affect India's agricultural export.

$\mathrm{H}_{2 \mathrm{a}}$ : GDP of trading countries positively affect India's agricultural export.

DIFFijt, absolute difference between the GDP per capita of both the trading economies (abs $\mid$ GDP per capita of India-GDP per capita of country $j \mid$ ) has been incorporated to measure the differential in the purchasing power of the inhabitants. The differential measures the taste variation in both the economies. With increase in the taste differential, bilateral trade between two economies generally deteriorates (Linder, 1961; PingGing, 2013). Economies with different purchasing power have varied demand and hence a negative impact on bilateral exchange of goods and services. 
92 | FOCUS: Journal of International Business, Volume 2, Issue 2

$\mathrm{H}_{30}$ : Difference between the GDP per capita of both the trading countries does not affect India's agricultural export.

$\mathrm{H}_{3 \mathrm{a}}$ : Difference between GDP per capita of both the trading countries positively/negatively affects India's agricultural export.

LabRatioijt (Exporter-to-importer labour participation ratio) measures the proportional labour Indian market is able to offer in order to enhance agricultural sector. India is an agrarian economy and agricultural sector requires both unskilled and semiskilled labour. The labour participation captures the size of the labour market in an economy and the variable labour participation ratio measures the proportional size of the labour market. Therefore, the variable is expected to have a positive impact on India's agricultural exports. The variable measures whether a labour intensive market like India is able to promote agricultural trade.

$\mathrm{H}_{40}$ : Labour Ratio of trading countries does not affect India's agricultural export.

$\mathrm{H}_{4 \mathrm{a}}$ : Labour Ratio of trading countries positively affects India's agricultural export.

Trade Openness of the importer country (TOPNjt) measures whether the importing countries have policies supporting trade liberalisation and whether such policies are encouraging trade with India. Liberal trade policies (openness) suggest fewer hassles for trade in terms of tariffs, quotas, and technical barriers. A more liberal importing economy will definitely offer a better market for Indian agricultural produce.

$\mathrm{H}_{5 \mathrm{o}}$ : Trade openness of importing Asian countries does not affect India's agricultural export.

$\mathrm{H}_{5 \mathrm{a}}$ : Trade openness of the partner countries positively affects India's agricultural export.

Common Border (Com_Borijt) measures whether sharing a common border has

a positive impact on India's agricultural exports. With a common border, the cost of transporting and trading reduces leading to an increase in trade. However, with expansion of trade network and better techniques of packing available for perishable products, common border as a determinant of trade is becoming insignificant. Some recent studies (Satputra, 2013) have found common border as insignificant for trade. We incorporate the variable as a dummy variable with value 1 in case both the countries are sharing a common border otherwise 0 .

$\mathrm{H}_{60}$ : Common border of the trading partners no impact on India's agriculture export.

$\mathrm{H}_{6 \mathrm{a}}$ : Common border of the trading partners positively affects India's agriculture export.

Distance (DISijt) captures the impact of transportation and delivering cost associated with international trade. With increase in the distance between the two trading economies, the transaction cost increase and hence the variable is expected to have a negative impact on India's agricultural exports.

$\mathrm{H}_{70}$ : Distance between the member countries does not affect India's agricultural export. 
$\mathrm{H}_{7 \mathrm{a}}$ : Distance between the member countries negatively affects India's agricultural export.

Common Language (Com_Lanijt) has been incorporated to measure whether ease in verbal communication has any impact on India's agricultural trade. In case both the trading economies share a common official language, they tend to reduce the cost associated with verbal interpretation. The variable is expected to have a positive impact on India's agricultural exports.

$\mathrm{H}_{80}$ : Common language of trading partners has no impact on India's agriculture export.

$\mathrm{H}_{8 \mathrm{a}}$ : Common language of trading partners positively affects India's agriculture export.

To capture the impact of RTAs on India's agriculture export, we have taken two variables, SAPTAc and APTAc. The variables are capturing whether these two RTAs are helping India to create trade and whether these forms of integration are supporting India's agricultural sector. Both the regional trade variables are taken as dummy variables. The first variable, SAPTAc takes the value 1 if both the trading partners are part of SAARC for a given year otherwise 0 .

$\mathrm{H}_{90}$ : Membership of SAPTA for both India and its trading partner does not affect India's agricultural exports.

$\mathrm{H}_{9 \mathrm{a}}$ : Membership of SAPTA for both India and its trading partner positively affects India's agricultural export.

Similarly, the value of the variable APTAc is 1 if both countries $i$ and $j$ are part of the same agreement in a particular year and 0 in case if there regional agreement APTA is not negotiated between India and its trading partner.

$\mathrm{H}_{100}$ : Membership of APTA for both India and its trading partner does not affect India's agriculture export.

$\mathrm{H}_{10 \mathrm{a}}$ : Membership of APTA between trading countries positively affects India's agriculture export.

\subsection{Research Methodology}

The study covers panel data regression due to the presence of two-dimensional nature of the data. For capturing panel data regression model, we can use either fixed effects or random effects specifications. Fixed effects (FE) model specification examines the individual and/or time specific effects by correlating individual effects with the explanatory variable. Moreover, each cross-sectional entity is identified as entities separate from one another. However, a significant limitation of FE model is that it cannot be a better measure in case the individuals or entities do not vary or vary insignificantly across time. As our study covers both time variant and invariant variables simultaneously, we have initially examined the explanatory variables by applying both 
94 | FOCUS: Journal of International Business, Volume 2, Issue 2

random effects as well as fixed effects. Subsequently, Hausman test was used to choose between random effects and fixed effects. The result for Hausman test supported fixed effects specification.

Hausman and Taylor (1981) suggested a model where individual effects are correlated with the explanatory variable and time invariant regressors can be accommodated. HT estimation is intensively used in order to overcome the limitations associated with both FE and RE model. Therefore, the study examines the explanatory variables using FE and HT estimation to capture the impact of RTAs on India's agricultural trade.

\subsection{Results and Analysis}

Table1 below presents the results generated for the model using fixed effects and HT estimation for a period of 13 years from 2001-2013. Gravity model fits well to capture the impact of RTAs on India's agricultural exports with adjusted Rsquare around $86 \%$. The results for both the models are more or less similar. Most of the conventional variables of gravity model are found to be statistically significant and the results for large number of coefficient are found to be as expected. The coefficient for GDP of India is significant and positive for Indian agricultural exports. With increase in GDP (economic size), India is able to offer a better market for agricultural products. The larger economic size (GDP) of the partner economy also affects Indian agricultural exports positively by offering a big market. The results for bilateral distance indicate that increase in transportation cost discourages exports. The coefficient for distance is found to be negative and significant. However, the results for common border and linguistic proximity are found to be insignificant for India's agricultural exports. Improvements in transportation and exchange networks might have contributed to such results. The coefficient for difference in GDP per capita is found to be insignificant (for both fixed effects and HT estimation). This indicates that difference in purchasing power of the two nations does not affect agricultural trade. A possible reason could be that agricultural products are basic, undifferentiated products with relatively low income elasticity.

The result for trade openness of trading partner is found to be positive and significant. This is in line with expectation indicating that economies which have trade supportive policies are a better market for India's agricultural produce. Moreover, the results indicate a positive coefficient for exporter-to-importer labour participation ratio; a larger labour participation of India as compared to associated economy is supplementing India's agriculture. 
Table 1: Estimates of Gravity model with Fixed Effects and Hausman Taylor Estimation

(Results for the period 2001-2013)

\begin{tabular}{|c|c|c|c|c|c|c|}
\hline & \multicolumn{3}{|c|}{ Fixed effects } & \multicolumn{3}{c|}{ HT estimation } \\
\hline Laexp & Coef. & Std. Err & p-value & Coef. & Std. Err & p-value \\
\hline Lingpro & ------ & ------ & ------ & -0.004 & 0.353 & 0.991 \\
\hline c_bor & ------ & ------ & ------ & -0.565 & 0.595 & 0.342 \\
\hline Aptac & $0.365^{* *}$ & 0.189 & 0.055 & $0.392^{*}$ & 0.168 & 0.019 \\
\hline Saptac & 0.036 & 0.062 & 0.566 & 0.046 & 0.060 & 0.449 \\
\hline Diffijt & 0.121 & 0.237 & 0.609 & -0.036 & 0.208 & 0.863 \\
\hline Lgdpi & 0.416 & 0.278 & 0.135 & $0.473 * *$ & 0.265 & 0.074 \\
\hline Lgdpj & $1.152^{*}$ & 0.272 & 0.000 & $1.067 *$ & 0.259 & 0.000 \\
\hline Ldisij & ------- & ------- & ------ & $-2.94 *$ & 1.079 & 0.006 \\
\hline Ltopnj & $1.09 *$ & 0.199 & 0.000 & $0.97 *$ & 0.190 & 0.000 \\
\hline Loglab & $5.38^{*}$ & 1.911 & 0.005 & $3.60 *$ & 1.493 & 0.016 \\
\hline Const & -14.48 & 1.002 & 0.000 & -3.626 & 4.074 & 0.373 \\
\hline \multicolumn{2}{|r|}{ R-squared } & $87.48 \%$ & & & Prob(F-statistic) & 0.000000 \\
\hline Adjusted R-squared & $85.99 \%$ & & Durbin-Watson stat & 1.425980 \\
\hline S.E. of regression & 0.167625 & & & 58.76718 \\
\hline
\end{tabular}

The coefficients for both the regional trade agreements (SAPTAc and APTAc) are found to be positive. However, while the results for SAPTA are insignificant, the results for APTA are found to be significant. This indicates a better market offered by APTA members as compared to SAARC. China and Republic of Korea are vital participants of APTA and China ranks in top 5 importers of India's processed agricultural produce (www.commerce.nic.in). Moreover, Bangladesh and Sri Lanka which are members of both the RTAs are significant importers of fresh onions, pulses, fruits and vegetable seeds, etc (http://www.india-exports.com/agro.html). SAARC nations are also trying to improve agricultural trade among member nations. In 2011, SAARC nations signed an agreement to boost and support agriculture by forming a SAARC regional seed bank. 


\subsection{Conclusion}

The study found the traditional variables of gravity, namely GDP of India, GDP of importing countries and distance are significant determinants of India's agricultural exports. Economic size of trading economies and bilateral transportation cost are playing an important role in fetching agricultural trade for India. Moreover, economies having liberal trade policies (trade openness) are supporting export of India's agricultural produce. However, time invariant variables such as common border and linguistic proximity are found to be insignificant. The results for variables of our interest, APTA and SAARC are found to be positive for India's agriculture but the results for APTA are more encouraging than SAARC. Overlapping membership of Bangladesh and Sri Lanka (two important agricultural importers from India) in SAARC and APTA might have generated such results. Moreover, SAARC nations are still working upon the area of agriculture; for instance they have come up with a SAARC regional seed bank to further support intra-regional agricultural trade.

\section{References}

Akhter, Naseem \& Ghani, Ejaz. (2010). Regional integration South Asia: An analysis of Trade flows using the gravity model. The Pakistan Development Review, 49(2): 105-118.

Archarya Subash. (2012). A panel data analysis of Foreign trade determinants of Nepal: Gravity model approach. NRB working paper series, NRB-WP-13, 2012. Retrieved from www.nrb.org.np.

Guilhot, L. (2010). Assessing the impact of main East-Asian free trade agreements using a gravity model. First results. Economic Bulletin, 30(1): 282-291.

Jayasinghe, Sampath \& Sarker, Rakhal. (2004). Effects of regional Trade Agreements on Trade in agrifood products: Evidence from Gravity Modeling. Working Paper 04WP374.Center for agricultural and rural development Lowa State University. Ames, Lowa

Korinek, J. \& M. Melatos (2009). Trade Impacts of Selected Regional Trade Agreements in Agriculture. OECD Trade Policy Papers, No. 87, OECD Publishing. http://dx.doi.org/10.1787/225010121752 
Lee, Jong-Wha \& Shin, Kwanho (2006). Does regionalism lead to more global trade Integration in East Asia? The North American Journal of Economics and Finance. 17(3):283-301.

Linder, S.B.(1961). An Essay on Trade and Transformation. New York: John Wiley.

Makochekanwa, Albert (2012). Impact of regional trade agreements on Trade in Agrifood products: Evidence from Eastern and Southern Africa. Paper submitted to African Economic Conference 2012.

Muhammad K. \& Yucer A. (2010). Trade effects of regional trade agreements: Trade creation and trade diversion within the Western Hemisphere, International Journal of Economic Issues. 3(2): 221-238.

Peter A. G., Afesorgbor, Sylvanus \& Van, Bergeijk(2011). Multi-Membership and the Effectiveness of Regional Trade Agreements in Western and Southern Africa: A Comparative Study of ECOWAS and SADC (Institute of Social Sciences Working Paper No. 520). Retrieved from: http://ssrn.com/abstract $=1766522$

PingJing, B. (2013). Bilateral Trade of China and the Linder Hypothesis: A gravity Model Approach. Available at:

http://www.diva-portal.org/smash/get/diva2:605666/FULLTEXT01.pdf

Rahman, M., Shadat, W.B., \& Das, N.C. (2006). Trade potential in SAFTA : An application of augmented gravity model (Centre for Policy Dialogue (CPD) Working paper no. 61).Retrieved from website: http://ideas.repec.org/p/pdb/opaper/61.html

Saputra, Mahardika Putu Adi (2014). The effects of regionalism and infrastructure on Bilateral trade: An augmented gravity Analysis for ASEAN. International Journal of Economics and Finance. 6(3): 88:95.

Vollrath, Thomas L. \& Hallahan, Charles B. (2009).Economic costs and payoffs of bilateral/regional trade agreements. Agricultural and Applied Economics Association working paper no.49375). 
98 |FOCUS: Journal of International Business, Volume 2, Issue 2

\section{Annexure 1}

List of products covered under WTO for agriculture (along with HS code). The study collected data for export each product individually and then the summation of all is done in order to estimate the total bilateral exports from India to its significant Asian Partners.

\begin{tabular}{|l|l|l|l|}
\hline (i) & \multicolumn{3}{|l|}{ HS Chapters 1 to less fish and fish products, plus* } \\
\hline (ii) & HS Code & 2905.43 & (mannitol) \\
\hline & HS Code & 2905.44 & (sorbitol) \\
\hline & HS Heading & 33.01 & (essential oils) \\
\hline & HS Headings & 35.01 to 35.05 & (albuminoidal substances, modified starches, glues) \\
\hline & HS Code & 3809.10 & (finishing agents) \\
\hline & HS Code & 3823.60 & (sorbitol n.e.p.) \\
\hline & HS Headings & 41.01 to 41.03 & (hides and skins) \\
\hline & HS Heading & 43.01 & (raw furskins) \\
\hline & HS Headings & 50.01 to 50.03 & (raw silk and silk waste) \\
\hline & HS Headings & 51.01 to 51.03 & (wool and animal hair) \\
\hline & HS Headings & 52.01 to 52.03 & (raw cotton, waste and cotton carded or combed) \\
\hline & HS Heading & 53.01 & (raw flax) \\
\hline & HS Heading & 53.02 & (raw hemp) \\
\hline
\end{tabular}

Source: www.wto.org 